\title{
Dams and Reservoirs
}

\section{Book review}

\section{The men who drowned Dolgarrog}

John Lawson-Reay, Llygad Gwalch Cyf, Gwynedd, Wales, UK, 27 November 2018, ISBN 1845242866 (paperback), 164 pp.

During the evening of 2 November 1925 in North Wales, Eigiau Dam broke, releasing $4500000 \mathrm{~m}^{3}$ of water into the Conwy valley below. The torrent of water overwhelmed Coedty dam, causing a second (cascade) failure. The sudden combined release of water and large boulders flooded the downstream village of Dolgarrog, destroying buildings and resulting in the deaths of ten adults and six children.

John Lawson-Reay is a local historian living in Llandudno, near Dolgarrog. He was a self-employed freelance press photographer and film maker, and worked for BBC TV for 37 years.

Based on records from the now defunct Aluminium Corporation, which built and operated the dams to supply water for its industrial processes, and other local information sources, the author has written a gripping and informative, illustrated non-technical account of the historical events surrounding the disaster, including the design and construction of the dams and the post-incident inquest.

The designer of both Eigiau and Coedty dams was 27-year-old Ralph Freeman, who later became the senior partner of Freeman Fox and Partners. He was the first witness to be questioned by the coroner. His answers are quoted in some detail in the book and were somewhat guarded, understandably in the circumstances. Eventually, the jury returned a verdict of accidental death, caused by the bursting of the dam wall due to inadequate foundations.

Salutary reading for any dam engineer, the author reveals the commercial, political, management and social failures that led to the disaster, and attempts to lay blame. He accuses the dam owner, engineers and coroner of professional incompetence, criminal neglect and corporate cover up. Engineers reading the book will make their own judgments, which won't necessarily agree with everything the author has got to say!

Roger Lewis 